\title{
BRAZILIAN MOSQUITO (DIPTERA: CULICIDAE) FAUNA. I. Anopheles SPECIES FROM PORTO VELHO, RONDÔNIA STATE, WESTERN AMAZON, BRAZIL
}

\author{
Sirlei Antunes MORAIS (1), Paulo Roberto URBINATTI (1), Maria Anice Mureb SALLUM (1), Adriana Akemi KUNIY (2), Gilberto Gilmar MORESCO (2), \\ Aristides FERNANDES (1), Sandra Sayuri NAGAKI (1) \& Delsio NATAL (1)
}

\begin{abstract}
SUMMARY
This study contributes to knowledge of Anopheles species, including vectors of Plasmodium from the western Brazilian Amazon in Porto Velho, Rondônia State. The sampling area has undergone substantial environmental changes as a consequence of agricultural and hydroelectric projects, which have caused intensive deforestation and favored habitats for some mosquito species. The purpose of this study was to diagnose the occurrence of anopheline species from collections in three locations along an electric-power transmission line. Each locality was sampled three times from 2010 to 2011. The principal adult mosquitoes captured in Shannon trap were Anopheles darlingi, An. triannulatus, An. nuneztovari 1.s., An.gilesi and An. costai. In addition, larvae were collected in ground breeding sites for Anopheles braziliensis, An. triannulatus, An. darlingi, An. deaneorum, An. marajoara, An. peryassui, An. nuneztovari 1.s. and An. oswaldoi-konderi. Anopheles darlingi was the most common mosquito in the region. We discuss Culicidae systematics, fauna distribution, and aspects of malaria in altered habitats of the western Amazon.
\end{abstract}

KEYWORDS: Anopheles; Amazon Basin; Culicidae; Fauna records; Malaria epidemiology.

\section{INTRODUCTION}

Anophelinae mosquitoes are important vectors of Plasmodium that can cause malaria in humans ${ }^{2,6}$. Additionally, Anopheles species may be involved in the dynamics of transmission of microfilariae ${ }^{1}$ and arboviruses $^{22}$. In Brazil, Anopheles (Nys.) darlingi Root, An. (Nys.) aquasalis Curry, An. (Nys.) triannulatus (Neiva and Pinto), An. (Nys.) braziliensis (Chagas), An. (Ker.) cruzii Dyar and Knab, and An. (Ker.) bellator Dyar and Knab are primary vectors of human Plasmodium, whereas other Anopheles species may be either secondary or local vectors $^{10,34}$

Mechanisms of vectorial competence of Anopheles species to infection by a Plasmodium species are only partially understood. Moreover, they are likely related to the physiological, genetic and immunological characteristics of the species to acquire and transmit the pathogen ${ }^{26,27}$. The vectorial capacity of competent mosquito populations is determined by ecological factors, e.g., human-blood-feeding frequency, mean longevity, mosquito density relative to humans, and number of infective bites ${ }^{3,37}$. Consequently, a particular species of Anopheles may be an important vector in one region, but of minor or no importance in another.

Relationships between ecological zones and frequency of Anopheles species in a small geographical area are unknown. In addition to climate factors and regional flora and fauna, factors affecting oviposition, feeding and survival of a species include environmental determinants that may be associated to both human activities and alterations in land use. Thus, road construction, mining, human settlements, hydroelectric damming, agriculture and cattle farms have indirectly propitiated increasing in the incidence of human malaria $9,17,18,33,35$.

The state of Rondônia has been largely impacted by changes in natural ecosystem, caused by intensive deforestation and changes in land use. Moreover, the state possesses a great hydroelectric potential because of the abundance of water resources, and this potential is being exploited to produce energy. Environmental changes of natural ecosystem include intense deforestation, partial obstruction of rivers and creeks, damming of water and formation of large lakes, which are favoring habitats for mosquito vector species, including Anophelinae species.

Currently, there is a concern about the impact of these activities on human and environmental health because they may favor some mosquito vector species, and promote the migration of susceptible humans into the region ${ }^{36}$. Among the vector species that can be favored by ecological changes it is included Anopheles species that are vectors of human Plasmodium. Although this scenario is broadly accepted by the entomological surveillance program, the effect of power transmission lines on the epidemiology of human malaria has not been assessed.

(1) Departamento de Epidemiologia, Faculdade de Saúde Pública, Universidade de São Paulo, São Paulo, SP, Brazil.

(2) JGP Consultoria e Participações Ltda., Rua Américo Brasiliense 615, 04715-003 São Paulo, SP, Brazil.

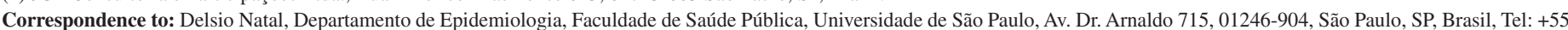
113061 7710, FAX +55 113061 7926, E-mail: natal@usp.br 
MORAIS, S.A.; URBINATTI, P.R.; SALLUM, M.A.M.; KUNIY, A.A.; MORESCO, G.G.; FERNANDES, A.; NAGAKI, S.S. \& NATAL, D. - Brazilian mosquito (Diptera: Culicidae) fauna. I. Anopheles species from Porto Velho, Rondônia State, Western Amazon, Brazil. Rev. Inst. Med. Trop. Sao Paulo, 54(6): 331-5, 2012.

The objective of this paper is to add further records of Anopheles species to a regional fauna checklist, providing a compendium of the species recorded in the western Brazilian Amazon. We also comment about malaria prevention in the study area related with the local anopheline fauna.

\section{MATERIAL AND METHODS}

Study area. Collections were undertaken near Porto Velho, Rondônia State $\left(8^{\circ} 45^{\prime} \mathrm{S} 63^{\circ} 53^{\prime} \mathrm{W}\right)$ at approximately $84 \mathrm{~m}$ altitude. The investigated area is inserted in the Amazon biome and the vegetation is composed of humid tropical forest of the Madeira River Basin. The annual temperature varies from 20 to $30^{\circ} \mathrm{C}$, and rainfall is higher than $2000 \mathrm{~mm}^{16}$. Landscape in the study area was severely modified decades ago by excessive land use. The local environmental revels predominant open fields used for pasture and restricted spot of residual forest. The human settlements are restricted to small villages and scattered rural habitations. All the area is permeated by streams and pools for cattle water supplies; on the other hand it characterizes favorable conditions for Culicidae development.

A new hydroelectric dam is currently under construction in Porto Velho, which already hosts a large hydroelectric complex. The mosquito collection sites include three rural localities situated along the $22 \mathrm{~km}$ planned trajectory of a new power transmission line. This extension line will interconnect the city of Porto Velho to the main line which is being prepared to transfer electric force, from the generation site to the consumption area, for about more than $2000 \mathrm{~km}$ eastern. Around each site, five ponds were searched for larvae and one point was chosen for adult collection using a Shannon trap. Mosquitoes were collected three times between February 2010 and January 2011, totaling 54 collections. Collection sites are shown in Figure 1.

Adult collections. Adult mosquitoes were captured using a Shannon trap with a light power-supply ${ }^{32}$. The traps were installed adjacent to rural areas considered to represent anthropic environments ${ }^{31}$. Shannon traps allow the capture of adult females attracted by light and humans near the collection area. According to MISSAWA et al. ${ }^{23}$, Shannon traps can be used as alternatives to human baiting for capture of anthropophilic mosquitoes in studies that have the objective of detecting the presence of vectors. Due to the light effects, this technical alternative is useful to sort a lot of mosquito's species. Since anophelinae mosquitoes are known by different adaptations for zoophily and endophily ${ }^{3}$.

After capture, mosquitoes were quickly anesthetized with ethyl acetate and separated into mini plastic vials in silica gel. Species were identified by morphological characters using adult identification keys $^{19,13}$. Approximately $20 \%$ of adults were pinned and deposited in the Entomological Reference Collection of the Faculdade de Saúde Pública (FSP-USP), Universidade de São Paulo, Brazil. Other samples were labeled and frozen at $-70{ }^{\circ} \mathrm{C}$ for future reference.

Immature collections. Immature stages were collected along the future electrical extension line, in small or large, permanently or temporarily ponds. Samples of immature mosquitoes were collected with $80 \mathrm{~mL}$ plastic dippers along the pond's border. A volume proportional to the flooded area of each pond was estimated: about one dipper-volume per square meter ${ }^{12}$. Larvae were fixed in situ in $70 \%$ ethanol and pupae were stored in plastic containers and kept alive in the laboratory until adult emergence. Larval and pupal exuviae and genitalia associated with adult forms were mounted on microscope slides and deposited in the FSP-USP collection.

\section{RESULTS}

Distribution. The numbers of anopheline adults collected in the study area is shown in Table 1. A total of 862 adults were captured using a Shannon trap. Anopheles darlingi represented $98 \%$ of all mosquitoes

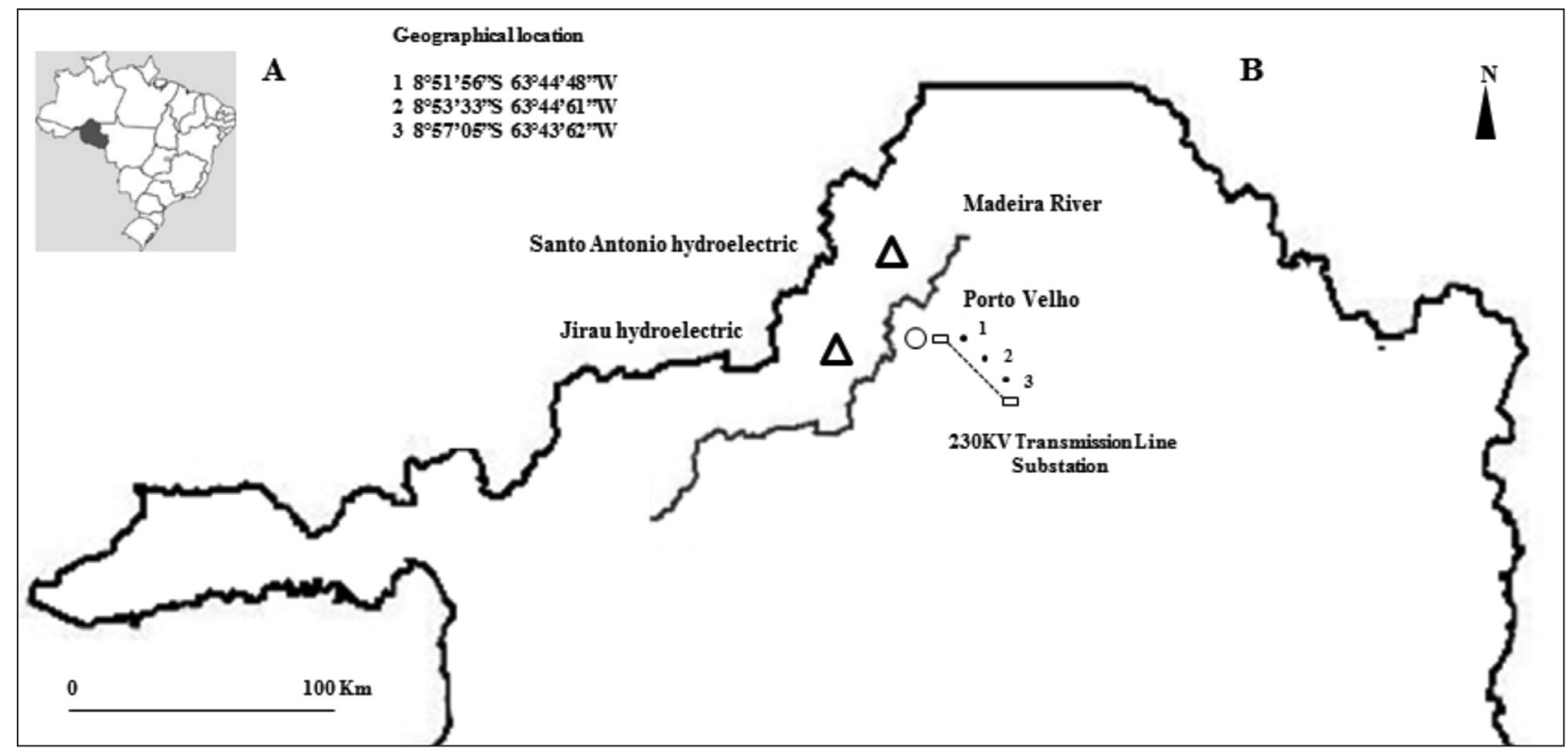

Fig. 1 - Map of anopheline mosquito collection sites. A Rondônia State in Brazil. B northern Rondônia. Numbers indicate sampling sites $\mathbf{1}, 2$ and 3. 


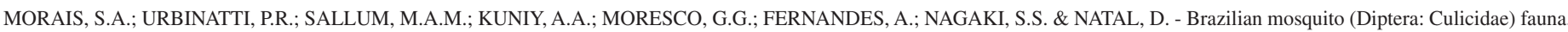
I. Anopheles species from Porto Velho, Rondônia State, Western Amazon, Brazil. Rev. Inst. Med. Trop. Sao Paulo, 54(6): 331-5, 2012.

collected. Collection site number 2 had a higher number of adults. In few numbers, the other species are: An. triannulatus, An. nuneztovari, An. gilesi and An. costai.

The results of anopheline larvae are shown in Table 2. A total of 201 larvae were collected. Anopheles braziliensis was the most present species, representing $40.2 \%$ of the total, followed by An. triannulatus (26.8\%), An. darlingi (13.4\%) and An. deaneorum Rosa-Freitas (5.4\%). Less collected species were: Anopheles marajoara Galvão and Damasceno, An. peryassui Dyar and Knab, An. nuneztovari 1.s., and An. oswaldoi 1.s., which together accounted for $14.2 \%$ of the total. Larvae were collected more frequently in site 1 .
Approximately $20 \%$ of adult mosquitoes captured in the field were deposited in the FSP-USP Collection under accession numbers E13342-E13433 and E13507-E13517. Larval and pupal exuviae and genitalia slides associated with adult forms were deposited under accession numbers E13434-E13506 and E13518-E13611. Other specimens were labeled, stored in tubes with alcohol, and preserved at $-70{ }^{\circ} \mathrm{C}$.

\section{DISCUSSION}

Shannon trap collections resulted in a greater number of captures, but low species variation, with An. darlingi being the most collected

Table 1

Species of the genus Anopheles collected as adults in Shannon trap, in Porto Velho, Rondônia State, Brazil. Samples were collected in three distinct occasions, from February 2010 to January 2011

\begin{tabular}{|c|c|c|c|c|c|c|}
\hline Collection Dates & Adult species & Site 1 & Site 2 & Site 3 & Total & $\%$ \\
\hline \multirow[t]{2}{*}{ February 2010} & An.(Nys.) darlingi & 22 & 30 & 212 & 264 & 100 \\
\hline & & & & & 264 & 100 \\
\hline \multirow[t]{6}{*}{ September 2010} & An. (Nys.) darlingi & 2 & 184 & 45 & 231 & 96.25 \\
\hline & An. (Nys.) triannulatus & - & 2 & 1 & 3 & 1.25 \\
\hline & An. (Nys.) nuneztovari 1.s. & 4 & - & - & 4 & 1.7 \\
\hline & An. (Lph.) gilesi & 1 & - & - & 1 & 0.4 \\
\hline & An. (Ano.) costai & - & - & 1 & 1 & 0.4 \\
\hline & & & & & 240 & 100 \\
\hline \multirow[t]{4}{*}{ January 2011} & An. (Nys.) darlingi & 4 & 299 & 49 & 352 & 98.4 \\
\hline & An. (Nys.) triannulatus & 1 & - & - & 1 & 0.2 \\
\hline & An. (Nys.) nuneztovari 1.s. & 3 & 1 & 1 & 5 & 1.4 \\
\hline & & & & & 358 & 100 \\
\hline Total & & 37 & 516 & 309 & 862 & \\
\hline
\end{tabular}

Table 2

Anopheles larvae collected in Porto Velho, Rondônia, Brazil. Samples were collected three times from February 2010 to January 2011

\begin{tabular}{|c|c|c|c|c|c|c|}
\hline Collection Dates & Larvae species & Site 1 & Site 2 & Site 3 & Total & $\%$ \\
\hline \multirow[t]{8}{*}{ February 2010} & An.(Nys.) darlingi & 8 & 1 & - & 9 & 11.6 \\
\hline & An .(Nys.) triannulatus & 13 & 8 & - & 21 & 27.3 \\
\hline & An.(Nys.) braziliensis & 1 & 4 & 35 & 40 & 52.0 \\
\hline & An.(Nys.) marajoara & - & 4 & - & 4 & 5.2 \\
\hline & An.(Nys.) oswaldoi-konderi & 1 & - & - & 1 & 1.3 \\
\hline & An. (Ano.) peryassui & 1 & - & - & 1 & 1.3 \\
\hline & An. (Nys.) nuneztovari 1.s. & 1 & - & - & 1 & 1.3 \\
\hline & & & & & 77 & 100 \\
\hline \multirow[t]{7}{*}{ September 2010} & An.(Nys.) darlingi & 18 & - & - & 18 & 21.4 \\
\hline & An .(Nys.) triannulatus & 12 & - & - & 12 & 14.3 \\
\hline & An.(Nys.) braziliensis & 34 & 3 & - & 37 & 44.1 \\
\hline & An .(Nys.) marajoara & - & 3 & - & 3 & 3.6 \\
\hline & An. (Ano.) peryassui & 5 & - & 1 & 6 & 7.1 \\
\hline & An. (Nys.) nuneztovari 1.s. & 7 & 1 & - & 8 & 9.5 \\
\hline & & & & & 84 & 100 \\
\hline \multirow[t]{5}{*}{ January 2011} & An.(Nys.) braziliensis & 4 & - & - & 4 & 10.0 \\
\hline & An .(Nys.) triannulatus & 8 & 10 & 3 & 21 & 52.5 \\
\hline & An. (Nys.) nuneztovari 1.s. & 2 & 1 & 1 & 4 & 10.0 \\
\hline & An. (Nys.) deaneorum & - & 10 & 1 & 11 & 27.5 \\
\hline & & & & & 40 & 100 \\
\hline Total & & 115 & 45 & 41 & 201 & \\
\hline
\end{tabular}




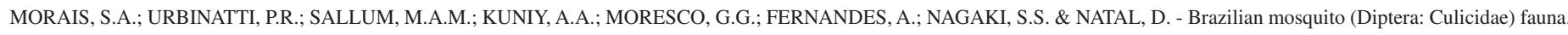
I. Anopheles species from Porto Velho, Rondônia State, Western Amazon, Brazil. Rev. Inst. Med. Trop. Sao Paulo, 54(6): $331-5,2012$.

mosquitoes. It is not surprising that An. darlingi is an important malaria vector in endemic areas of the Amazon: it is considered highly anthropophilic and is ubiquitous in the region's considerable freshwater bodies $^{14,17}$.

Although immature collections resulted in fewer mosquitoes, they yielded higher species variation (Table 2). Anopheles braziliensis was the most common, followed by An. triannulatus, An. darlingi, An. nuneztovari 1.s., An. marajoara, An. deaneorum, An. peryassui and An. oswaldoi-konderi. Surprisingly, An. darlingi larvae were rarely found in the larval habitats sampled. The low number of An. darling $i$ immatures suggests that the breeding sites of this species were not located in the study area. Anopheles triannulatus and An. braziliensis were frequently collected in the region. These species are probably less anthropophilic than An. darlingi and are characterized as secondary malaria vectors ${ }^{34}$. These results justify the use of Shannon traps in combination with immature collections, because the Shannon operates attractively and the latter passively. Both techniques enlarge fauna evaluation quality.

We found one female with morphological characteristics typical of Series Arribalzagia (Table 1). This specimen was identified as An.costai based primarily on the geographical distribution previously described for the species $^{27,28}$.

Anopheles (Ano.) costai Fonseca and Ramos, An. (Ano.) forattinii Wilkerson and Sallum and An. (Ano.) mediopunctatus (Lutz) belong to the Arribalzagia Series of Anopheles (Anopheles). Because of morphological similarities, An. costai and An. forattinii have been previously misidentified as An. mediopunctatus. More recently, these species have been diagnosed based on features of the male genitalia, larvae and pupae. As a result, An. costai was resurrected from synonymy with An. mediopunctatus and An. forattinii was described and validated as a member species of the Arribalzagia Series ${ }^{28,29}$.

Although Anopheles (Nyssorhynchus) nuneztovari Gabaldón is commonly recorded in the Brazilian Amazon ${ }^{8}$, BERGO et al. ${ }^{4}$ suggested that under the name An. nuneztovari cytotype A could be more than one species, including An. goeldii. Anopheles nuneztovari A is morphologically similar to, but chromosomally distinct from An. nuneztovari cytotypes $\mathrm{B} / \mathrm{C}$ which occur in Venezuela and Colombia, respectively ${ }^{7}$. CALADO et al. ${ }^{5}$ corroborated the morphological hypothesis of BERGO et al..$^{4}$, asserting that An. goeldii was a valid species, using morphology, the mitochondrial coxl gene and the nuclear White gene. CALADO et al. ${ }^{5}$ resurrected An. goeldii from synonymy with An. nuneztovari. However, it is possible that both species occur in Brazil and we consequently adopted the nomenclature An. nuneztovari 1.s. in the present study until further research is conducted in Rondônia State.

Anopheles (Nys.) konderi Galvão and Damasceno are morphologically similar to An. (Nys.) oswaldoi in larval, pupal and adult female characters, but are distinguished by characters of the male genitalia ${ }^{11}$. Based on morphological comparisons, LANE ${ }^{20}$ synonymized An. konderi with An. oswaldoi. Later, FLORES-MENDOZA et al. ${ }^{11}$ observed differences in the apex of the aedeagus in the male genitalia that were consistent in samples from distinct geographic locations, and thus resurrected the species from synonymy. As only one immature of this species was found, which emerged as a female, it was not possible to identify the species with certainty. The specimen was therefore labeled in Table 2 as An. oswaldoi-konderi. Both species have been reported from Rondônia State $^{21}$. Recently, SALLUM et al. ${ }^{29}$ demonstrated to have more than one species under the name An. konderi. Furthermore, MOTOKI et al. ${ }^{24}$ using sequences of COI mtDNA, single copy White nuclear gene, and the second internal transcribed spacer of the ribosomal DNA corroborate the presence of An. konderi in Rondônia State, showing that Rondônia population is closely related to representatives from Paraná State.

During operation period, apparently, power transmission line does not represent a major environmental impact in Rondônia State because they do not interfere directly with water resources or flooding. By the construction period, moreover, the potential risk for new malaria transmission cycles in the region is low because workers are primarily active during daylight, whereas vectors generally blood feed at night in the peri/intradomicile ${ }^{3,15}$. Nevertheless, it is important that construction companies should maintain malaria prevention and vector control programs, because the main vector was detected along the line. Immigration of susceptible humans to malaria is worrisome because the primary regional vector occurs in areas around the power transmission line.

\section{RESUMO}

Fauna brasileira de mosquitos (Diptera: Culicidae). I. Espécies de Anopheles de Porto Velho, estado de Rondônia, oeste da Amazônia, Brasil

Este estudo contribui para o conhecimento de espécies de Anopheles, incluindo vetores de Plasmodium do oeste da Amazônia brasileira, em Porto Velho, no estado de Rondônia. Esta região vem passando por mudanças ambientais, como consequência de agricultura extensiva e projetos hidroelétricos que causam desmatamento, favorecendo o desenvolvimento de algumas espécies de mosquitos. Assim, a proposta deste estudo é registrar a presença de espécies de anofelinos na área, sendo conduzidas coletas de mosquitos em três locais, ao longo de uma linha de transmissão de energia elétrica. Cada uma das localidades foi amostrada três vezes, no período de 2010 a 2011. Os principais mosquitos adultos capturados em armadilhas de Shannon foram Anopheles darlingi, An. triannulatus, An. nuneztovari 1.s., An.gilesi e An. costai. Assim como as formas larvárias Anopheles braziliensis, An. triannulatus, An. darlingi, An. deaneorum, An. marajoara, An. peryassui, An. nuneztovari 1.s. e An. oswaldoi-konderi, coletadas em criadouros. Anopheles darlingi foi a espécie mais coletada na região. Em adição, discutiu-se sistemática de Culicidae, distribuição de fauna e aspectos da malária em ambientes modificados do oeste da Amazônia brasileira.

\section{REFERENCES}

1. Amuzu H, Wilson MD, Boakye DA. Studies of Anopheles gambiae s.l (Diptera: Culicidae) exhibiting different vectorial capacities in lymphatic filariasis transmission in the Gomoa district, Ghana. Parasit Vectors. 2010;3:85-90.

2. Arruda M, Carvalho MB, Nussenzweig RS, Maracic M, Ferreira AW, Cochrane AH. Potential vectors of malaria and their different susceptibility to Plasmodium falciparum and Plasmodium vivax in northern Brazil identified by immunoassay. Am J Trop Med Hyg. 1986;35:873-81.

3. Barros FSM, Honório NA, Arruda ME. Mosquito anthropophily: implications on malaria transmission in the northern Brazilian Amazon. Neotrop Entomol. 2010;39:1039-43. 
MORAIS, S.A.; URBINATTI, P.R.; SALLUM, M.A.M.; KUNIY, A.A.; MORESCO, G.G.; FERNANDES, A.; NAGAKI, S.S. \& NATAL, D. - Brazilian mosquito (Diptera: Culicidae) fauna. I. Anopheles species from Porto Velho, Rondônia State, Western Amazon, Brazil. Rev. Inst. Med. Trop. Sao Paulo, 54(6): 331-5, 2012.

4. Bergo ES, Souto RN, Galardo AK, Nagaki SS, Calado DC, Sallum MA. Systematic notes on Anopheles Meigen (Diptera: Culicidae) species in the state of Amapá, Brazil. Mem Inst Oswaldo Cruz. 2007;102:373-6.

5. Calado DC, Foster PG, Bergo ES, Santos CLS, Galardo AKR, Sallum MAM. Resurrection of Anopheles goeldii from synonymy with Anopheles nuneztovar (Diptera, Culicidae) and a new record for Anopheles dunhami in the Brazilian Amazon. Mem Inst Oswaldo Cruz. 2008;103:791-99.

6. Cerutti Jr C, Boulos M, Coutinho AF, Hatab MC, Falqueto A, Rezende HR, et al. Epidemiologic aspects of the malaria transmission cycle in a area of very low incidence in Brazil. Malar J. 2007;6:33.

7. Conn JE. A genetic study of the malaria vector Anopheles nuneztovari from Western Venezuela and Colombia. J Am Mosq Control Assoc. 1990;6:400-5.

8. Conn JE, Mitchell SE, Cockburn AF. Mitochondrial DNA analysis of the neotropical malaria vector Anopheles nuneztovari. Genome. 1998;41:313-27.

9. Duarte EC, Fontes CJ. Associação entre a prudução anual de ouro em garimpos e incidência de malária em Mato Grosso - Brazil, 1985-1996. Rev Soc Bras Med Trop. 2002;35:665-8.

10. Ferreira E. Distribuição geográfica dos anophelinos no Brasil e sua relação com o estado atual da erradicação da malária. Rev Bras Malariol Doenças Trop. 1964;16:329. 48.

11. Flores-Mendoza C, Peyton EL, Wilkerson RC, Lourenço-de-Oliveira R. Anopheles (Nyssorhynchus) konderi Galvão and Damasceno: neotype designation and resurrection from synonymy with Anopheles (Nyssorhynchus) oswaldoi (Peryassú) (Diptera: Culicidae). Proc Entomol Soc Wash. 2004;106:118-32.

12. Fontanarrosa MS, Marinone MC, Fischer S, Orellano PW, Schweigmann N. Effects of flooding and temperature on Aedes albifasciatus development time and larval density in two rain pools at Buenos Aires University city. Mem Inst Oswaldo Cruz. 2000;95:787-93

13. Forattini OP. Culicidologia Médica. São Paulo: EDUSP; 2002.

14. Galardo AKR, Arruda M, Couto AARD, Wirtz R, Lounibos LP, Zimmerman RH Malaria vector incrimination in three rural riverine villages in the Brazilian Amazon. Am J Trop Med Hyg. 2007;76:461-9.

15. Gomes AC, Paula MB, Natal D, Gotlieb SLD, Mucci LF. Effects of flooding of the River Paraná on the temporal activity of Anopheles (Nyssorhynchus) darlingi Root (Diptera: Culicidae), at the border State of Mato Grosso do Sul and São Paulo, Brazil. Rev Soc Bras Med Trop. 2010;43:516-22.

16. Hammond S. The comparative world atlas. Canada: Hammond World Atlas Corporation; 2007.

17. Katsurugawa TH, Cunha RP, Souza DC, Gil LH, Cruz RB, Silva AA, et al. Malária e aspectos hematológicos em moradores da área de influência dos futuros reservatórios das hidrelétricas de Santo Antonio e Jirau, Rondônia, Brasil. Cad Saude Publica. 2009;25:1486-92.

18. Koifman S. Geração e transmissão da energia elétrica: impacto sobre os povos indígenas no Brasil. Cad Saude Publica. 2001;17:413-23.

19. Lane J. Neotropical Culicidae. Vol. I. São Paulo: Universidade de São Paulo; 1953a.

20. Lane J. Neotropical Culicidae. Tribe Culicini, Deinocerites, Uranotaenia, Mansonia, Orthopodomyia, Aedomyia, Aedes, Psorophora, Haemagogus, tribe Sabethini, Trichoprosopon, Wyeomyia, Phoniomyia, Limatus and Sabethes. Vol. II. São Paulo: Universidade de São Paulo; 1953b.
21. Marrelli MT, Honório NA, Flores-Mendoza C, Lourenço-de-Oliveira R, Marinotti O, Kloetzel JK. Comparative susceptibility of two members of the Anopheles oswaldoi complex, An. oswaldoi and An. konderi, to infection by Plasmodium vivax. Trans $\mathrm{R}$ Soc Trop Med Hyg. 1999;93:381-4.

22. Medlock JM, Snow KR, Leach S. Potential transmission of West Nile virus in the British Isles: an ecological review of candidate mosquito bridge vectors. Med Vet Entomol. 2005;19:2-21.

23. Missawa NA, Ribeiro ALM, Maciel GBML, Zeilhofer P. Comparison of capture methods for the diagnosis of adult anopheline populations from State of Mato Grosso, Brazil. Rev Soc Bras Med Trop. 2011;44:555-60.

24. Motoki MT, Bourke BP, Bergo ES, Da Silva AM, Sallum MA. Systematic notes of Anopheles konderi and its first record in Paraná State, Brazil. J Am Mosq Control Assoc. 2011;27:191-200

25. Natal D, Urbinatti PR, Malafronte RS, Rezende HR, Cerutti Jr. C, Sallum MAM First record of Anopheles (Anopheles) costai Fonseca \& Ramos, 1939 in Espírito Santo State, Brazil. Rev Inst Med Trop Sao Paulo. 2007;49:323-6.

26. Reisen WK, Pradhan SP, Shrestha JP, Shrestha SL, Vaidya RG, Shrestha JD Anophelinae mosquito (Diptera: Culicidae) ecology in relation to malaria transmission in the inner and Outer Terai of Nepal, 1987-1989. J Med Entomol. 1993;30:664-82.

27. Reisen WK, Meyer RP, Milby MM, Presser SB, Emmons RW, Hardy JL, et al. Ecological observations on the 1989 outbreak of St. Louis encephalitis virus in the Southern San Joaquin valley of California. J Med Entomol. 1992;29:472-82.

28. Sallum MAM, Flores DC. Ultrastructure of the eggs of two species of Anophele (Anopheles) Meigen (Diptera, Culicidae). Rev Bras Entomol. 2004;48:185-92.

29. Sallum MA, Marrelli MT, Nagaki SS, Laporta GZ, Dos Santos CL. Insight into Anopheles (Nyssorhynchus) (Diptera: Culicidae) species from Brazil. J Med Entomol. 2008:45:970-81.

30. Sallum MAM, Wilkerson RC, Forattini OP. Taxonomic study of species formerly identified as Anopheles mediopunctatus and resurrection of An. costai (Diptera: Culicidae). J Med Entomol. 1999;36:282-300.

31. Service MW. Mosquito ecology: field sampling methods. London: Chapman \& Hall 1993

32. Shannon RC. Methods for collecting and feeding mosquitoes in jungle yellow fever studies. Am J Trop Med Hyg. 1939;19:131-40.

33. Silva-Nunes M, Codeço CT, Malafronte RS, Silva NS, Juncansen C, Muniz TP, et al. Malaria on the Amazonian frontier: transmission dynamics, risk factors, spatial distribution, and prospects for control. Am J Trop Med Hyg. 2008;79:624-35.

34. Tadei WP, Thatcher BD. Malaria vectors in the Brazilian Amazon: Anopheles of the subgenus Nyssorhynchus. Rev Inst Med Trop Sao Paulo. 2000;42:87-94.

35. Vasconcelos $\mathrm{CH}$, Novo EM, Donalisio MR. Uso do sensoriamento remoto para estudar a influência de alterações ambientais na distribuição da malária na Amazônia brasileira. Cad Saude Publica. 2006;22:517-26.

36. World Health Organization. Malaria control in complex emergencies: an inter-agency field handbook. Geneva: World Health Organization; 2005.

37. Zimmerman RH. Ecology of malaria vectors in the Americas and future direction. Mem Inst Oswaldo Cruz. 1992;87(suppl 3):371-83

Received: 15 October 2011

Accepted: 31 May 2012 


\section{LIBRARY OF THE SÃO PAULO INSTITUTE OF TROPICAL MEDICINE}

Website: www.imt.usp.br/portal

Address: Biblioteca do Instituto de Medicina Tropical de São Paulo da Universidade de São Paulo Av. Dr. Enéas de Carvalho Aguiar, 470. Prédio 1 - Andar térreo.

05403-000 São Paulo, SP, Brazil.

Telephone: 5511 3061-7003 - Fax: 5511 3062-2174

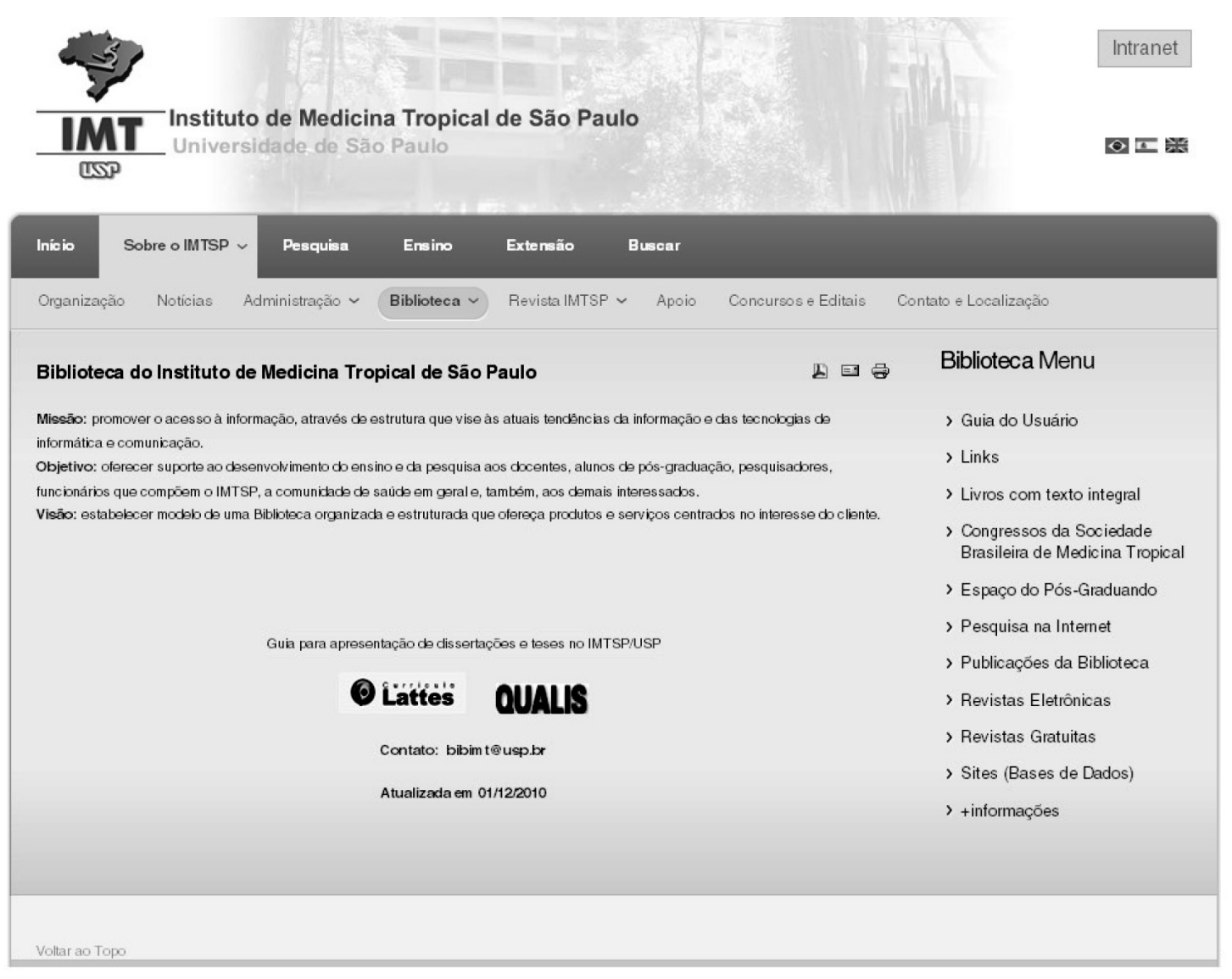

The Library of the São Paulo Institute of Tropical Medicine (IMTSP Library) was created on January 15,1959 in order to serve all those who are interested in tropical diseases. To reach this objective, we select and acquire by donation and / or exchange appropriate material to be used by researchers and we maintain interchange between Institutions thorough the Journal of the São Paulo Institute of Tropical Medicine, since the Library has no funds to build its own patrimony.

The IMTSP Library has a patrimony consisting of books, theses, annals of congresses, journals, and reference works.

The collection fo journals existing in the Library can be verified through the USP - Bibliographic Database - OPAC - DEDALUS http://dedalus.usp.br:4500/ALEPH/eng/USP/USP/DEDALUS/start of the USP network. 